Uniwersytet im. Adama Mickiewicza, Poznań

\title{
Emocjonalne i racjonalne aspekty ukraińskich tendencji eurointegracji
}

$Z_{\text {jak }}$ każdym rokiem ulega zmianie postrzeganie zarówno samej Europy, jak również miejsca Ukrainy w procesie formalnego i realnego zbliżenia do granic Unii Europejskiej. Dzisiejszy świat znajduje się w stanie ciągłych napięć, które szczególnie obserwowane są we względnie stabilnych krajach. Właśnie droga rozwoju relacji „światów” i kultur w konstruktywnym kluczu wymaga kompleksowego podejścia do analizy teoretycznych i praktycznych aspektów minimum pokojowego współistnienia, a w każdym razie harmonijnej współpracy wszystkich postępowych sił ludzkości.

Brak jasno sprecyzowanej przyszłości i kompleksy wynikające z przeszłości niezwykle ostro wpływają na kryteria odbioru na Ukrainie światowych procesów integracyjnych. Rozumienie konieczności czynienia „czegoś” dość słabo współgra ze spersonalizowanym udziałem obywateli w prowadzeniu kraju do europejskich wartości. Na poziomie opinii społecznej zbliżenie do wartości europejskich staje się jednak stopniowo nieuniknioną realnością. Ukraina faktycznie jest już zaangażowana w kluczu konceptualnym w globalne ekonomiczne i kulturowe procesy - na ulicach miast tłoczą się pojazdy zagranicznej produkcji, w kinach mają miejsce premiery światowych hitów, a trzecia część ludności korzysta z usług różnorodnych zagranicznych i krajowych firm turystycznych.

Pod względem strukturyzacji społeczeństwa obserwuje się na Ukrainie głównie syndromy społeczeństwa postsowieckiego, które nie tylko dławią gospodarkę, ale hamują również postęp w kierunku europejskiego wyboru.

Każdy na Ukrainie, jak i w każdym innym normalnym kraju, pragnie lepszego życia. Wizualnie i faktycznie takie „lepsze” życie widziane jest w Zachodniej Europie. Ale oczywistość konieczności podążania w zachodnim kierunku dla wielu na Ukrainie nie jest obiektywną realnością. Pierwszą, i być może, główną przeszkodą w drodze do Europy dla ukraińskiej nacji jest Rosja. Właśnie ten kraj ściśle utrzymuje w swojej sferze 
wpływu najbliższych sąsiadów, odgrywając rolę ważnej geopolitycznej figury. I chociaż obecny „duch Moskwy” jest zaledwie tylko wątlym odgłosem imperialnej tradycji, to jednak w zupełności wystarcza go do odczuwalnego hamowania ukraińskich euroatlantyckich procesów.

Przy czym rosyjski wpływ często przejawia się nie przez proste dyrektywy (co, faktycznie, niemożliwe jest dzisiaj), a za pomocą luk w świadomości kilku pokoleń ludności Ukrainy i w ramach pewnej terytorialnej specyfiki, bliskiej określonemu faworyzowaniu. Mowa jest w pierwszej kolejności o południowym wschodzie, gdzie poparcie dla rosyjskiej polityki zbliża się do pełnego solidaryzmu.

Niszowym stymulatorem rosyjskiego wpływu można nazwać kompleks ,pogranicza”, który kształtował się przez stulecia i obecnie, jak nigdy, zyskał na aktualności. Warto zauważyć, że z tego kompleksu korzystają i inni wielcy gracze na światowej arenie (w szczególności Amerykanie). Na czym polega idea ,pogranicza”? Idea ta bazuje na tym, że Ukraina stanowi wieczny bufor między kulturami i cywilizacjami i jej przypada w udziale stałe balansowanie między silniejszymi sąsiednimi wpływami, nikomu nie oddając przy tym pierwszeństwa.

Słabość tej koncepcji dla kraju polega na faktycznym niezrozumieniu nie tylko realnych perspektyw, ale i znacznemu zagubieniu się w teraźniejszości, a także mitologizowanej przeszłości. Na przykład, doktor nauk ekonomicznych Stefan Wowkanicz liczy, że „w ciagu prawie trzynastu lat Ukraina była poligonem dla aprobowania idei naszych bliskich, ale nie zawsze bardzo bliskich sąsiadów w różnych segmentach swojej, jakoby narodowej, a w rzeczywistości dalekiej od ukraińskiej polityki - ekonomicznej, społecznej, edukacyjnej, religijnej, wojskowej, ekologicznej itd."1. Sama koncepcja podobnego podejścia dowodzi poczucia podrzędności, przy czym często generowanej przez samych Ukraińców.

Percepcja rzeczywistości Ukraińców porównywalna jest z dekadenckimi tendencjami, często nieuzasadnionymi, jednak w przewadze swojej kładącymi nacisk na problemy ekonomiczne. Tendencje te mają stosunkowo dziwne i nieracjonalne odzwierciedlenie w opinii społecznej - istnieje pogląd, że Ukraina stanowi pole światowego eksperymentu, gdzie „testuje się” (podobnie, jak broń na wojnie) różnorodne technologie. Przy czym, w charakterze eksperymentatorów występują różne siły - począwszy od

1 S. Wowkanycz, Granicznost': jestiestwiennaja, nawiejannaja ili „,naproczaninnaja”, „Zierkało Niedieli” 2006, nr 24. 
przybyszów z innych planet do „syjonistycznych mędrców”. Podobne androny wnoszą koloryt do opinii społecznej, jednak nie mają perspektyw funkcjonowania w cywilizowanym społeczeństwie.

O niebezpieczeństwie braku wyrazistych szacunkowych i pozycyjnych kryteriów pisze się i mówi dziś na Ukrainie bardzo często. Wspomniany powyżej profesor S. Wowkanycz mówi: ,[...] ten niewidzialny fenomen sprzyja uświadomieniu sobie i adekwatnej ocenie oczywistych naszych granic, w których znaleźliśmy się (lub możemy się znaleźć), w szczególności społeczno-ekonomicznych (UE), polityczno-wojskowych (NATO i sojusz obronny WNP), kulturowo-religijnych (katolicyzm i prawosławie - zachodnia, łacińska i bizantyjsko-słowiańska kultura), społeczno-psychologicznych - pragmatyzm rynkowy (indywidualizm) i idealizm kolektywizmu, językowo-informacyjnych (sąsiedztwo stref wpływu globalizacji i asymilacji dwóch światowych języków - angielskiego i rosyjskiego) itd."

Wydaje się, że zwykłe wyliczenie współrzędnych napięcia świadomości na Ukrainie jest wystarczające, aby zostać owładniętym atmosfera „pogranicza”, atmosferą problematyczności w zakresie samoidentyfikacji. Najtrudniejszym w ogólnym zarysie ukraińskiej nieokreśloności jest właśnie brak należytego samodzielnego trzonu wewnętrznej i zagranicznej polityki w stosunku do Unii Europejskiej.

Z historycznego punktu widzenia najbardziej zgubna stała się polityka wielowektorowa, którą w istocie wyznawała cała ukraińska wierchuszka z niewielką przerwą po „pomarańczowej rewolucji”. Polityka „umiarkowanej drogi" nieuchronnie prowadziła do utraty impulsu nie tylko do eurointegracji, ale również do stosunkowo chłodnych stosunków z Rosją. Polityka ta służyła raczej osobistym interesom mizernej grupy na czele z „guru” wielowektorowości, Leonidem Kuczmą. Właśnie drogą szantażu i drobnych intryg, żenujących gier z Zachodem i Rosją na przemian z panicznym strachem obu biegunów Leonid Kuczma trzymał ster pięćdziesięciomilionowego kraju przez dziesięć lat.

Kiedy pojawił się problem zmiany władzy politycznej na Ukrainie w 2004 roku, temat integracji europejskiej stanowił jeden z mechanizmów przedwyborczych. W 2004 roku sam temat zbliżenia z Unią Europejską przybrał wypaczone formy, przekształcił się w sztandar wyborczy trzymających się kurczowo resztek władzy bankrutów politycznych. Przykła-

2 Ibidem. 
dowo, we wszystkich regionalnych mass mediach rozwinęła się kampania informacyjna skierowana na dyskredytację zachodniego kierunku rozwoju kraju. Ekspert Instytutu Polityki Aleksander Palij w swoim badaniu tego problemu wskazywał na palące fakty kampanii wyborczej 2004 roku: „stało się jasne, że administracja prezydenta przystąpiła do rozsyłania wykazów z materiałami o charakterze antyeuropejskim do obowiązkowej publikacji”3. Tytuły materiałów do obowiązkowej publikacji mówią same za siebie: „Członkostwo w UE będzie kosztować Ukrainę 25\% PKB”, „Ukraina na linii NATO. Cele NATO pozostają te same, co 50 lat temu - skończyć z Rosją”, „Nowe formy ekspansji amerykańskiej na Wschód”. Zrozumiałe jest, że w każdym z tych materiałów w negatywnym kontekście figuruje Juszczenko ${ }^{4}$.

Podobne materiały nie tylko pokazywały wadliwą formę (sama idea „wytycznych" nie współgrała z zachodnim systemem wartości demokratycznych), ale również pod względem treści - ucieczka od sformalizowanych priorytetów zachodniej integracji, którymi zasłaniali się ludzie Kuczmy. W pracach szefa administracji prezydenckiej ukierunkowanie na Europę wymieniane było jako perwszoplanowe zadanie. Przy tym ma miejsce przesada $\mathrm{z}$ najbardziej paradoksalnymi procesami w samej Europie: „Europejscy socjaldemokraci, którzy początkowo aktywnie występowali przeciw procesom integracji europejskiej, w ostatnim dziesięcioleciu stali się jej zwolennikami. Ponieważ w polityce ekonomicznej Unii Europejskiej przeważają neoliberalne koncepcje, to orientacja na europejską integrację gospodarczą oznacza jednoczesne uznanie liberalnej polityki gospodarczej" $"$.

Takie punkty widzenia należały do inspiratora wspomnianych antyeuropejskich „wytycznych”. Istota podobnej polityki podwójnych standardów polegała na elementarnym braku wiary w jakikolwiek postęp kraju w kierunku do Europy - sama działalność ekipy Kuczmy sprowadzała się do pełnego zubożenia narodu, co absolutnie sprzeczne było z ideami zbliżenia do wysokich standardów współpracy. Wiktor Miedwieczuk przyznawał, że „, dla Ukrainy [...] kurs na udział w strukturach europejskich,

3 O. Palij, Informacijna polityka włady-zagroza nacjonalnym interesam, www.tomenko.kiev.ua

4 Ibidem.

5 W. Medwieczuk, Duch i princyp socjsl-demokratii: ukrainska perspektywa, Kiev 2000, s. 110. 
na pełnoprawne członkostwo w UE jest tożsame z uznaniem liberalnych wartości i monetarystycznych metod gospodarczych"6.

Sama natura podobnych teorii ujawniła podwójny standard - chwytliwy jaskrawy plakat dla zagranicy (głównie w celu wyciagania wygodnych kredytów) i małostkowa polityka wewnątrz kraju (o wiele wygodniejsze jest utrzymywanie narodu w niewiedzy i sprowadzanie trudności do ,wrogich wpływów").

Na rozbicie podwójnego podejścia skierowana była w rzeczywistości polityka Wiktora Juszczenki. Starał się on zsynchronizować zewnętrzne i wewnętrzne strumienie świadomości narodu, zharmonizować politykę europejską. Jednak zadanie to było znacznie trudniejsze, niż wydawało się na pierwszy rzut oka. Pośrednio potwierdzało to również skrajnie niskie poparcie ze strony Prezydenta. Jego argumenty nieuchronnie wpływały na wyniki badania opinii społecznej, które sięgały zaledwie $10 \%$.

Na niepodległej Ukrainie, niezależnie od wyżej wspomnianych sił przeciwnych eurointegracji, działają siły zdrowo, pragmatycznie i systemowo pojmujące europejski wybór swojego kraju. Za pierwsze realne kroki do europejskiego wyboru uważa się działania mające miejsce dopiero po odzyskaniu niepodległości. Jednak pewna baza ustawodawcza pojawiła się jeszcze krótko przed rozpadem ZSRR. Były wtedy podpisane dokumenty deklaratywne z Unią Europejską.

Pozytywny impuls dla integracji europejskiej we współczesnej Ukrainie dała ,pomarańczowa rewolucja”. Nieprzypadkowo ogniskiem zapalnym i sprzeciwu dla fałszerstw stała się klasa średnia. Faktycznie byli to ludzie pracujący od ósmej do ósmej, władający kilkoma językami, zarabiający powyżej 1000 dolarów i odpoczywający w znanych kurortach. Nieprzypadkowo ta właśnie grupa skupiona była w Kijowie. Właśnie ci ludzie, realnie odczuwający wielkie europejskie możliwości i będący zmęczeni radzieckim „przyjacielem” werbalizowali najbardziej zrównoważone dążenie do Unii Europejskiej.

Może wydawać się dziwnym, jednak hasła europejskiej integracji były nie tylko przeinaczane, ale również wypaczone. Faktycznie, siły socjalistyczne wzięły w charakterze broni koncepcję „Budujemy Europe domu". Niby to, do żadnej Unii Europejskiej nie chcemy - sami damy sobie radę z siostrą Rosją. Jednak dla wszystkich rozsądnie myślących

6 Ibidem. 
ludzi zrozumiała była niedorzeczność tego typu poglądów, ponieważ Rosja nie tylko nie zbliżała się do Europy, ale od niej uciekała, oddalała się.

Ukraina staje się w pewnym sensie zakładniczką antagonizmów nowych krajów członkowskich Unii Europejskiej z Rosją. Najbardziej jaskrawym przykładem tego stanu rzeczy był sprzeciw Polski w uregulowaniu stosunków pomiędzy UE i Rosją, wywołany przede wszystkim planami gospodarczymi. Skutkiem tego antagonizmu była radykalna pozycja Polaków, która z kolei nie była akceptowana przez starych członków UE - Polska traciła autorytet. Znakomitym przykładem może tu być kwestia budowy gazociagu północnego na dnie Bałtyku. Wskutek takiej skomplikowanej kombinacji Ukraina zaczęła tracić szanse na szybszą integrację z europejskimi strukturami.

Problemem dzisiejszego wstapienia Ukrainy w aktywną fazę integracji europejskiej jest nieokreśloność samego sojuszu w wewnętrznej organizacji. Sukcesy gospodarcze i pewność siebie krajów UE nie mogły rozwiązać kwestii politycznych - w jaki sposób skonsolidować państwa ze swej natury bardzo różnorodne. Klęska wspólnej konstytucji świadczyła o rozproszeniu samej Unii, jej niezdolności do monolitycznego konstruowania wewnętrznych i zewnętrznych priorytetów.

Dla Ukrainy bardziej niezrozumiałe i przykre jest nie tyle praktyczno-teoretyczne rozbicie i zróżnicowanie UE, ile słaby impuls wyczekiwania i mgliste perspektywy. Te demokratyczne ukraińskie siły, które popierają politykę eurointegracji, otrzymały zaledwie częściowe poparcie ze strony Unii podczas wyborów, przy czym, poparcie sprowadzało się do akcji PR-owskich, a nie do długoterminowych priorytetowych zobowiązań. Nie zadziwia fakt, że dla społeczeństwa ukraińskiego tego typu fikcja stała się oczywista i poparcie wspaniałomyślnie obojętnej Unii Europejskiej jest traktowane już jako bonus.

Jednym z ważniejszych problemów, oczekujących rozwiązania w najbliższym czasie jest rozgraniczenie w świadomości ukraińskiego społeczeństwa pojęć Unia Europejska i NATO. Kwestia ta jest tym ważniejsza, że stopień poparcia dla NATO jest o wiele mniejszy od poparcia UE. Dla wielu polityków dziś NATO stanowi straszak z czasów propagandy radzieckiej. O wrogości NATO w czasach radzieckich napisano wiele, a dziś nowe postrzeganie sojuszu jeszcze nie jest dojrzałe. O stopniu zafałszowania i podmianie dwóch pojęć świadczy sam fakt, że NATO był jedynym w propagandzie radzieckiej skrótem niepodlegającym tłumaczeniu. Przecież NATO, jako organizację obronną, przyjęte było prezentować pod po- 
stacią wojującego agresora. I ten ostry „sos” zachował się na Ukrainie w retoryce wielu polityków.

Obojętność ze strony kierownictwa UE w stosunku do Ukrainy doprowadziła do tego, że polityczny Olimp stopniowo zdobywają prorosyjskie siły, które przetaczają kraj na pozycje sprzed lat kilkudziesięciu. Jedyną szansą dla Ukrainy jest skok gospodarczy - wtedy to politycy będą w stanie prowadzić dialog z Unią Europejską nie w randze „ubogich krewnych", a w charakterze poważnego partnera.

\section{Summary}

At present, Ukraine is searching for an optimum manner of cooperation with the European Union. However, it is doubtful whether the EU approval procedure can be completed in the present decade. Fortunately, a number of problems are imaginary rather than real, and they are the aftermath of the reality of the Soviet Union. To understand the specific Ukrainian character with respect to European integration is significant both for Ukraine herself and for the beneficial development of the EU member states. 
